\title{
Rapid subglacial erosion beneath Pine Island Glacier, West Antarctica
}

\author{
A. M. Smith, ${ }^{1}$ C. R. Bentley, ${ }^{2}$ R. G. Bingham, ${ }^{3}$ and T. A. Jordan ${ }^{1}$ \\ Received 16 March 2012; revised 21 May 2012; accepted 28 May 2012; published 23 June 2012.
}

[1] We present measurements of ice thickness, gravimetry and surface elevation on Pine Island Glacier, West Antarctica, separated by a period of 49 years. At one station, on the main trunk of the glacier we measured a surface elevation lowering with no significant change in ice thickness. We interpret these as indicating subglacial erosion of $31.8 \pm$ $13.4 \mathrm{~m}$ at this location, at a mean rate over the measurement period of $0.6 \pm 0.3 \mathrm{~m} \mathrm{a}^{-1}$, and suggest that a current erosion rate of $\sim 1 \mathrm{~m} \mathrm{a}^{-1}$ is possible. Our results emphasize that locally, basal processes can have a significant effect on ice sheet changes, particularly where fast-flowing ice has an easily erodible bed. Citation: Smith, A. M., C. R. Bentley, R. G. Bingham, and T. A. Jordan (2012), Rapid subglacial erosion beneath Pine Island Glacier, West Antarctica, Geophys. Res. Lett., 39, L12501, doi:10.1029/2012GL051651.

\section{Introduction}

[2] The subglacial environment remains one of the least explored places on Earth and the processes operating there are still poorly understood. Subglacial erosion is one process that has proved particularly difficult to address, due to problems accessing glacier beds. Hence, progress in understanding contemporary subglacial erosion has been made primarily through proxy evidence and the application of theoretical studies [e.g., Lawson, 1993; Alley et al., 2003]. However, knowledge of subglacial erosion is still limited and its incorporation into numerical ice sheet models remains in its infancy [Hildes et al., 2004].

[3] Soft sediments beneath fast-flowing glaciers play a significant role in controlling ice flow, through their ability to deform, and their contribution to the basal drainage system [Cuffey and Paterson, 2010]. Complete removal of an unlithified sediment layer beneath a glacier could profoundly affect its dynamics. Limited evidence suggests that erosion rates beneath soft-bedded glaciers can be up to three orders of magnitude greater than elsewhere in the subglacial environment [Nolan et al., 1995; Motyka et al., 2006; Smith et al., 2007]. We present a comparison between two data sets from

\footnotetext{
${ }^{1}$ British Antarctic Survey, Natural Environment Research Council, Cambridge, UK.

${ }^{2}$ Department of Geology and Geophysics, University of WisconsinMadison, Madison, Wisconsin, USA

${ }^{3}$ School of Geosciences, University of Aberdeen, Aberdeen, UK.

Corresponding author: A. M. Smith, British Antarctic Survey, Natural Environment Research Council, Madingley Road, Cambridge CB3 0ET, UK. (amsm@bas.ac.uk)

C2012. American Geophysical Union. All Rights Reserved. 0094-8276/12/2012GL051651
}

Pine Island Glacier in West Antarctica and assess indications of subglacial erosion.

\section{Pine Island Glacier}

[4] Pine Island Glacier (PIG) drains part of the West Antarctic Ice Sheet (WAIS) into the Amundsen Sea. Observations have shown major changes in its dynamics and geometry in recent decades. Its speed increased by almost 50\% between 1992 and 2007 [Rignot, 2008] and acceleration continues [Scott et al., 2009]. The grounding line has retreated by up to $20 \mathrm{~km}$ since 1996 [Joughin et al., 2010], concurrent with lowering surface elevation and changes in the glacier's dynamics [Rignot, 1998; Shepherd et al., 2001; Scott et al., 2009; Wingham et al., 2009]. Ice discharge from PIG increased by $\sim 30 \mathrm{Gt} \mathrm{yr}^{-1}$ between 1996 and 2007 and it is currently the greatest single contributor to the mass imbalance of WAIS [Rignot, 2008]. Data were first acquired on PIG during the post-International Geophysical Year (IGY) Ellsworth Highland Traverse (EHT) [Shimizu, 1964] of 1960-61. Further data were collected between 2006 and 2009. Henceforth, the 1960-61 work will be referred to as IGY and that during 2006-09 as IPY (International Polar Year). Six IGY sites were revisited in IPY (Figure 1) and some measurements repeated (Table 1).

\section{Data Acquisition}

\subsection{Station Location and Navigation Errors}

[5] Navigation during IGY was by dead-reckoning controlled en-route by sun-sights. Position errors at sun-sight locations are $\pm 0.5 \mathrm{~km}$ and up to $\pm 5 \mathrm{~km}$ elsewhere. During IPY, positions were determined by dual-frequency GPS with a precision of $\pm 1 \mathrm{~m}$. Navigation errors are particularly significant for the comparisons between IGY and IPY data. Where surface topography is variable, failure to reoccupy IGY stations precisely could result in incorrect indications of elevation change. Likewise, where bed topography is rough, navigation errors could lead to incorrect interpretations of ice thickness change. To assess the effect of navigation errors we used additional data (seismic, radar, satellite altimetry and airborne gravity) and determined maximum deviations (of each measured parameter) across an area equivalent to that represented by the navigation error at each location (Table 1). Regional trends and local variability in surface elevation were given by observer's logs and en-route barometric observations in IGY. For IPY, orthogonal surface elevation profiles $(\sim 1 \mathrm{~km})$ were measured with dual frequency GPS, complemented by satellite altimetry [Bamber et al., 2009] and for sites EHT30.9 and EHT31, by additional GPS data [Smith and Scott, 2007]. Airborne radar data [Vaughan et al., 2006] were used to assess bed topography 

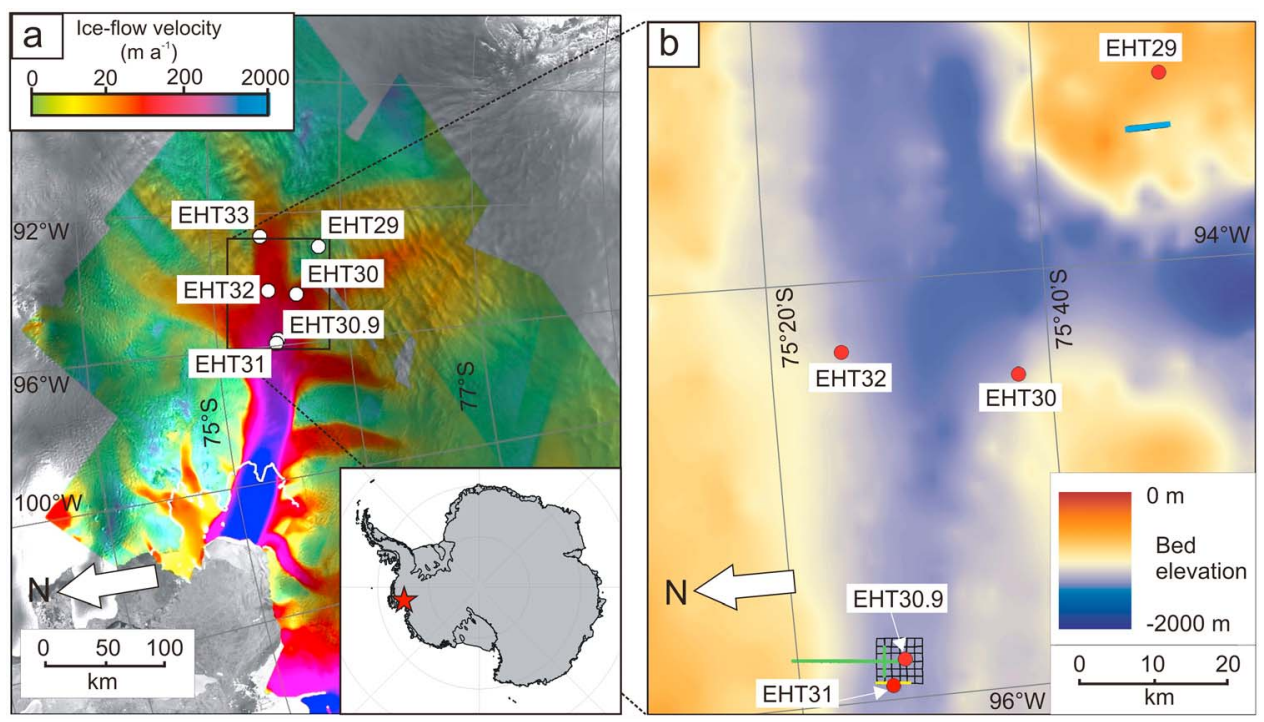

Figure 1. Location maps. (a) Pine Island Glacier showing ice velocity [Rignot et al., 2004]. White circles are measurement stations, white line is the 1996 grounding line [Rignot, 1998]. Station EHT30.9 was not previously identified explicitly, but lies where IGY seismic lines extending back from EHT31 toward EHT30, intersect those from IPY. Red star on inset map shows glacier location. (b) Close-up of station locations EHT29-32 (red circles), over bed topography [Vaughan et al., 2006]. Green and black lines are IPY seismic and ground radar lines, respectively. Short blue and yellow lines (upper-right near EHT29 and lower-middle near EHT31, respectively) show locations of radar data given in Figure 2.

at all sites. Ground radar $(3 \mathrm{MHz})$ and seismic reflection lines were also acquired around EHT 30.9 and EHT31 during IPY (Figure 1b). These show that bed topography in the area around these two sites is much smoother than elsewhere (Table 1 and Figure 2). Gravity field gradients were assessed using airborne survey data [Jordan et al., 2010].

\subsection{Seismic Data}

[6] Both projects used the travel times of seismic reflections from the glacier bed to determine ice thickness. Corrections were made for shot depths, based on snow and firn density measurements and supplementary seismic refraction data. Data quality influences the accuracy of the measured two-way travel times (twtt), giving an uncertainty of $\pm 1 \mathrm{~ms}$. There is little information from which to quantify the inherent repeatability of the seismic method, but repeat surveys elsewhere [Smith et al., 2007] suggest a precision of $\pm 5 \mathrm{~m}$. The twtt data, with equivalent ice thicknesses, are given in Table 1. A slight increase in firn density $\left(\sim 50 \mathrm{~kg} \mathrm{~m}^{-3}\right)$, with a corresponding increase in seismic velocity, is the reason why a small twtt decrease at site EHT31 indicates a slight thickening, rather than thinning of the ice.

\subsection{Gravimetry}

[7] Gravity observations were made using Lacoste and Romberg meters. In IGY, ties to Byrd Station were made at the beginning and end of the 3 month traverse. In IPY, a two-way aircraft tie (25 hours) was made to site EHT31 from a field camp on Rutford Ice Stream. Byrd and Rutford were tied, respectively, to base stations at McMurdo and Rothera and hence, to the international gravity network [Morelli et al., 1974]. Meter calibrations were checked using standard baselines. Both meters have long histories of slow, steady drift, and showed similarly low values during the surveys $\left(\leq 0.02 \mathrm{mGal} \mathrm{d}^{-1}\right)$, with no tares. Corresponding adjustments were distributed linearly with respect to time.
Observed gravity at EHT31 increased by $6.6 \pm 0.23 \mathrm{mGal}$ between IGY and IPY.

\subsection{Surface Elevation}

[8] Surface elevation during IGY was determined barometrically [Bentley and Ostenso, 1961]. Control was given by one return visit and an air-supported tie to sea level. During IPY, surface elevation was determined by dual frequency GPS. A geoid (Eigen-GL04C) correction of $+24 \mathrm{~m}$ enabled direct comparisons with the IGY data. All locations show a lowering of surface elevation (Table 1) but most errors are high $(46-58 \mathrm{~m})$ primarily due to the IGY altimetry and navigation uncertainties. Hence, although measured differences are large, most are less, or only slightly greater than the errors. At EHT31 however, the navigation error is reduced by a set of IGY sun-sights, giving a change in surface elevation of $-66 \pm 40 \mathrm{~m}$.

\subsection{Combined Errors}

[9] The combined errors (Table 1) show a simple pattern. In the centre of the glacier, smooth surface and bed topography, combined with low navigation errors, give a low uncertainty in measured changes. Elsewhere, errors are much greater and less can be concluded with certainty about changes since IGY. We therefore concentrate on results from EHT31; the other sites emphasize that not all re-measurements of earlier data will give significant results, even though indicated changes may be large.

\section{Rapid Subglacial Erosion}

[10] The elevation data at EHT31 show surface lowering between IGY and IPY whilst the seismic data show no significant change in ice thickness. These two results can only be reconciled by subglacial erosion, removing mass from beneath the ice and lowering the glacier surface without 
Table 1. Measurements, Uncertainties and Results ${ }^{\mathrm{a}}$

\begin{tabular}{|c|c|c|c|c|c|c|}
\hline & \multicolumn{6}{|c|}{ Station } \\
\hline & EHT29 & EHT30 & ЕНT30.9 & EHT31 & EHT32 & EHT33 \\
\hline \multicolumn{7}{|c|}{ Surface } \\
\hline Surface elevation (barometric), IGY (m) & 949 & 789 & & 752 & 791 & 798 \\
\hline Surface elevation (GPS), IPY (m) & 890 & 738 & 683 & 686 & 747 & 785 \\
\hline *Surface elevation uncertainty, IGY & $\pm 40 \mathrm{~m}$ & $\pm 40 \mathrm{~m}$ & $\pm 40 \mathrm{~m}$ & $\pm 40 \mathrm{~m}$ & $\pm 40 \mathrm{~m}$ & $\pm 40 \mathrm{~m}$ \\
\hline *Surface elevation uncertainty, IPY & $\pm 1 \mathrm{~m}$ & $\pm 1 \mathrm{~m}$ & $\pm 1 \mathrm{~m}$ & $\pm 1 \mathrm{~m}$ & $\pm 1 \mathrm{~m}$ & $\pm 1 \mathrm{~m}$ \\
\hline${ }^{*}$ Regional $(1-10 \mathrm{~km})$ surface elevation variability ${ }^{\mathrm{a}}$ & $\pm 37 \mathrm{~m}$ & $\pm 14 \mathrm{~m}$ & $\pm 2 \mathrm{~m}$ & $\pm 2 \mathrm{~m}$ & $\pm 10 \mathrm{~m}$ & $\pm 18 \mathrm{~m}$ \\
\hline${ }^{\dagger}$ Local $(<1 \mathrm{~km})$ surface elevation variability ${ }^{\mathrm{b}}$ & $\pm 20 \mathrm{~m}$ & $\pm 20 \mathrm{~m}$ & $\pm 2 \mathrm{~m}$ & $\pm 2 \mathrm{~m}$ & $\pm 20 \mathrm{~m}$ & $\pm 20 \mathrm{~m}$ \\
\hline Surface elevation change, GPS-barometric (m) & $-59 \pm 58$ & $-51 \pm 47$ & & $-66 \pm 40$ & $-44 \pm 46$ & $-13 \pm 48$ \\
\hline \multicolumn{7}{|c|}{ Bed } \\
\hline Seismic twtt, ms (ice thickness, m) IGY & & $998(1869)$ & $1046(1960)$ & $1049(1966)$ & 1047 (1962) & 1075 (2014) \\
\hline Seismic twtt, ms (ice thickness, m) IPY & & $1046(1963)$ & 1047 (1966) & $1048(1968)$ & $1044(1959)$ & $1056(1983)$ \\
\hline *Effect of surface elevation variability ${ }^{\mathrm{b}, \mathrm{c}}$ & $\pm 42 \mathrm{~m}$ & $\pm 24 \mathrm{~m}$ & $\pm 3 \mathrm{~m}$ & $\pm 3 \mathrm{~m}$ & $\pm 22 \mathrm{~m}$ & $\pm 27 \mathrm{~m}$ \\
\hline *Effect of bed topography variability ${ }^{\mathrm{d}}$ & $\pm 60 \mathrm{~m}$ & $\pm 125 \mathrm{~m}$ & $\pm 7 \mathrm{~m}$ & $\pm 7 \mathrm{~m}$ & $\pm 90 \mathrm{~m}$ & $\pm 75 \mathrm{~m}$ \\
\hline${ }^{\dagger}$ Uncertainty in seismic twtt, IGY \& IPY & & $\pm 3.8 \mathrm{~m}$ & $\pm 3.8 \mathrm{~m}$ & $\pm 3.8 \mathrm{~m}$ & $\pm 3.8 \mathrm{~m}$ & $\pm 3.8 \mathrm{~m}$ \\
\hline${ }^{\dagger}$ Technique repeatability & & $\pm 5 \mathrm{~m}$ & $\pm 5 \mathrm{~m}$ & $\pm 5 \mathrm{~m}$ & $\pm 5 \mathrm{~m}$ & $\pm 5 \mathrm{~m}$ \\
\hline${ }^{\dagger}$ Bed topography variability, $\mathrm{IGY}^{\mathrm{e}}$ & & $\pm 18 \mathrm{~m}$ & $\pm 4.8 \mathrm{~m}$ & $\pm 4.8 \mathrm{~m}$ & $\pm 9.5 \mathrm{~m}$ & $\pm 14.3 \mathrm{~m}$ \\
\hline${ }^{\dagger}$ Bed topography variability, IPY & & $\pm 2 \mathrm{~m}$ & $\pm 2.9 \mathrm{~m}$ & $\pm 2.9 \mathrm{~m}$ & $\pm 2.9 \mathrm{~m}$ & $\pm 7.6 \mathrm{~m}$ \\
\hline Ice thickness change (m) & & $+94 \pm 135$ & $+6 \pm 11$ & $+2 \pm 11$ & $-3 \pm 93$ & $-32 \pm 82$ \\
\hline \multicolumn{7}{|c|}{ Gravimetry } \\
\hline Observed gravity, IGY (mGal) & & & & 982639.3 & & \\
\hline Observed gravity, IPY (mGal) & & & & 982645.94 & & \\
\hline *Uncertainty from assuming linear drift (mGal) & & & & \pm 0.1 & & \\
\hline${ }^{\dagger}$ Effect of navigation uncertainty $(\mathrm{mGal})^{\mathrm{f}}$ & & & & \pm 0.18 & & \\
\hline *Reading precision $(\mathrm{mGal})$ & & & & \pm 0.1 & & \\
\hline Gravity change (mGal) & & & & $+6.6 \pm 0.23$ & & \\
\hline Surface elevation change, gravimetric $(\mathrm{m})$ & & & & $-29.8 \pm 13.4$ & & \\
\hline \multicolumn{7}{|c|}{ Subglacial Erosion } \\
\hline Net erosion $(\mathrm{m})$ & & & & $31.8 \pm 13.4$ & & \\
\hline Mean erosion rate, $1961-2009(\mathrm{~m})$ & & & & $0.6 \pm 0.3$ & & \\
\hline
\end{tabular}

${ }^{a}$ Individual uncertainties marked $*$ are r.m.s., for those marked ${ }^{\dagger}$ the maximum range of variation within the navigation uncertainty was used (i.e., more conservative than r.m.s.). Final uncertainties given for changes in surface elevation, ice thickness and gravity, and for erosion and erosion rate, are combinations of the individual uncertainties.

${ }^{\mathrm{b}}$ From satellite (visible, radar, laser) and airborne survey data [Vaughan et al., 2006; Bamber et al., 2009].

${ }^{\mathrm{c}}$ From barometry and observers logs (IGY) and GPS surveys (IPY).

${ }^{\mathrm{d}}$ From airborne [Vaughan et al., 2006] and ground radar surveys.

${ }^{\mathrm{e}}$ From range of seismic twtt values for individual shots.

${ }^{\mathrm{f}}$ Maximum gravity field gradient of $0.36 \mathrm{mGal} \mathrm{km}^{-1}$ [Jordan et al., 2010].

reducing the ice thickness. Seismic data [Smith and Scott, 2007] show the bed in this area is soft water-saturated sediments which will erode easily. Hence, we conclude that a significant quantity of sediment has been eroded from the glacier bed at this location since IGY. As the errors in the surface elevation data are high, we used the gravity data to calculate how much sediment has been removed. This required corrections for change in distance from the centre of the Earth (Free Air Correction) and the gravitational effect of the sediment itself (Bouguer Correction). These are $-0.3086 h_{s}$ and $+0.04188 h_{s} \rho_{s}$, respectively, where $h_{s}(\mathrm{~m})$ is the change in sediment thickness and $\rho_{s}\left(\mathrm{~g} \mathrm{~cm}^{-3}\right)$ is the sediment density. Sediment density is unknown but is unlikely to be $<1.8 \mathrm{~g} \mathrm{~cm}^{-3}$ or $>2.2 \mathrm{~g} \mathrm{~cm}^{-3}$ [Smith, 1997]. Hence, we assumed a value of $2.0 \pm 0.2 \mathrm{~g} \mathrm{~cm}^{-3}$. We also applied Free Air and Bouguer corrections for the measured increase in ice thickness, $h_{i},(+2 \mathrm{~m})$, assuming an ice density, $\rho_{i}$, of $0.915 \mathrm{~g} \mathrm{~cm}^{-3}$. The change in thickness of eroded basal sediments is thus given by $h_{s}=\left(\Delta g-h_{i}(-0.3086+\right.$ $\left.\left.0.04188 \rho_{i}\right)\right) /\left(-0.3086+0.04188 \rho_{s}\right)$. From the gravity measurements, $\Delta g=6.6 \mathrm{mGal}$. Hence, including the uncertainties in gravimetry $( \pm 0.23 \mathrm{mGal})$, ice thickness change $( \pm 11 \mathrm{~m})$ and assumed sediment density $\left( \pm 0.2 \mathrm{~g} \mathrm{~cm}^{-3}\right)$, we calculated a net erosion of $31.8 \pm 13.4 \mathrm{~m}$. Allowing for the ice thickness increase, surface elevation lowering measured gravimetrically is $29.8 \pm 13.4 \mathrm{~m}$. As our data points are few and our main results are from just one location, we cannot unequivocally rule out a simple observation error. However, the ice thickness measurements at EHT30.9 and the surface elevation measurements at EHT31, respectively, support our seismic and gravity interpretations at EHT31, so such an error is highly unlikely. Models of isostatic rebound in the area [Ivins and James, 2005; Riva et al., 2009] suggest an

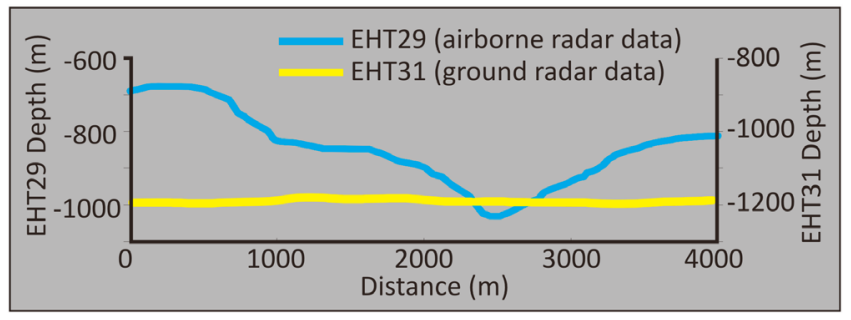

Figure 2. Examples of radar-derived bed topography showing smoother bed beneath the glacier (EHT31), than elsewhere (EHT29). Line locations are given in Figure 1b. 


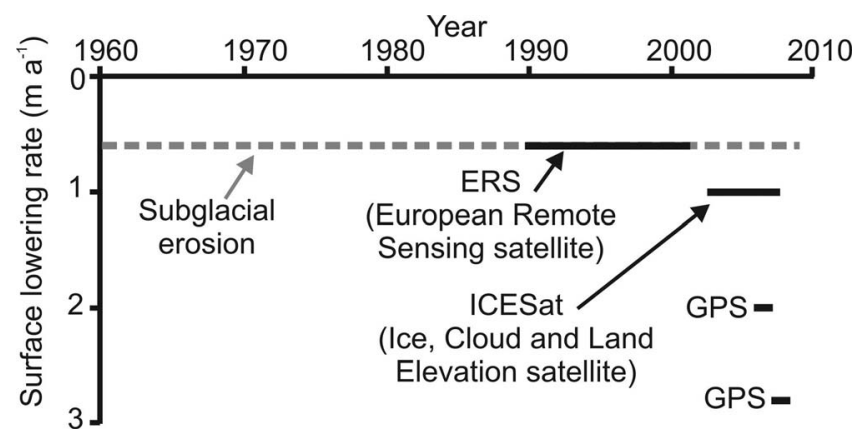

Figure 3. Mean erosion rate compared with mean rates of elevation change from satellite and GPS observations [Shepherd et al., 2001; Scott et al., 2009; Pritchard et al., 2009]. Coincidentally, the mean erosion rate since IGY equals the 1990-2001 surface lowering rate.

uplift rate of $5-10 \mathrm{~mm} \mathrm{a}^{-1}$, which would imply a slightly greater erosion than our calculated value.

\section{Conclusions and Discussion}

[11] Over the 49 year period, the mean erosion rate was $0.6 \pm 0.3 \mathrm{~m} \mathrm{a}^{-1}$. Measured and interpreted subglacial erosion rates are normally in the range $0.1-100 \mathrm{~mm} \mathrm{a}^{-1}$ [Hallet et al., 1996], significantly less than our value from PIG. The only comparable results from a similar setting are from Rutford Ice Stream [Smith et al., 2007] where $6 \mathrm{~m}$ of erosion was measured over a 6-year period. High erosion rates have also been reported from Iceland and Alaska: up to $3 \mathrm{~m} \mathrm{a}^{-1}$ during Little Ice Age glacier advances [Björnsson, 1996; Nolan et al., 1995] and up to $4 \mathrm{~m} \mathrm{a}^{-1}$ for the recent advance of Taku Glacier [Motyka et al., 2006]. Together with our new data from PIG, these represent a growing body of evidence for high erosion rates beneath soft-bedded, fastflowing ice.

[12] The nature of the subglacial material can influence ice flow [Anandakrishnan et al., 1998] and sustained rapid erosion increases the possibility that the eventual removal of soft sediment beneath a glacier will expose a different substrate, changing the ice dynamics [Motyka et al., 2006]. Seismic and airborne-gravity data from $\sim 20 \mathrm{~km}$ upstream of EHT32, respectively indicate a thin $(<10 \mathrm{~m})$ sediment layer beneath the ice, and underlying igneous rocks [Scott et al., 2010]. If current erosion rates are high, removal of this layer could occur over the next few decades. Considering the changes already happening on PIG, this possibility is of considerable significance; if erosion removes the intervening soft sediment, bringing the ice into direct contact with crystalline rocks, the basal drag is likely to increase, reducing the ice flow.

[13] PIG has been affected by both ice thinning and subglacial erosion over recent decades. Figure 3 compares the mean erosion rate with satellite- and GPS-derived surface lowering from the EHT31 area. Estimates of surface lowering since 2000 greatly exceed our mean erosion rate. Nevertheless, on decadal timescales, erosion can clearly be a significant component of the surface lowering at this location. We do not know the sequence of erosion that occurred. Discrete events or a continuous, variable-rate mechanism, are more likely than a constant rate over 49 years. For a continuous mechanism, erosion rate will probably be proportional to ice speed and the present-day rate will be much higher than the 49-year mean, as ice speed on PIG has increased in recent decades [Rignot, 2008], hence, a present-day erosion rate in the order of $1 \mathrm{~m} \mathrm{a}^{-1}$ is possible. In contrast, there are no recent indications (e.g., from satellite data) of large, discrete erosion events that could result from subglacial floods or meandering subglacial drainage channels. This suggests erosion by a continuous ice-bed interaction mechanism (e.g., subglacial sediment deformation). However, we cannot yet rule out discrete, water-related events, particularly as there is bathymetric evidence offshore for large volumes of water flowing beneath the ice in the past [Lowe and Anderson, 2003] and there is seismic evidence for free water in places beneath the glacier [Smith and Scott, 2007; Scott et al., 2010]. Modern navigation, surface elevation and ice thickness measurements could detect an erosion rate of $1 \mathrm{~m} \mathrm{a}^{-1}$ after as little as 5 years. Where the eroded sediment has been moved to is unknown, but considering ice flow and subglacial hydraulic gradients, it is most likely to have been transported downstream. The bed beneath the ice plain upstream of the grounding line [Corr et al., 2001] is one likely deposition site; eventual incorporation into till deposits at the grounding line [Anandakrishnan et al., 2007] is another. Recent, high sedimentation rates, associated with emerging meltwater plumes have been interpreted offshore in Pine Island Bay [Lowe and Anderson, 2002]. This is another possible location for deposition of the eroded material and would be consistent with our interpreted high erosion rates.

[14] Our results have implications for interpreting ice sheet change from satellite altimetry and, in particular, measuring ice thinning from surface lowering. As well as surface processes [Wingham, 2000; Helsen et al., 2008], basal mechanisms must also be considered. High subglacial erosion rates could lead to unrecognized errors if change is assessed from surface elevation measurements alone [Motyka et al., 2006]. Locally, it cannot be assumed that surface lowering over grounded ice can be attributed wholly to ice thinning. At wider scales, ice sheet mass balance estimates encompassing whole drainage basins agree well in some cases [Thomas et al., 2004; Rignot, 2008; Chen et al., 2008] although there is considerable variability [van den Broeke et al., 2011]. Our results do not bring into question these studies at the ice sheet scale, but do advise caution locally. This is particularly so where fast-flowing ice has a soft, easily erodible sediment bed.

[15] Acknowledgments. We thank numerous colleagues during IGY and IPY who helped collect the data and NERC Geophysical Equipment Facility (loan 847). Comments from M.A. King and a number of reviewers improved the paper.

[16] The Editor thanks Huw Horgan and John Anderson for assisting in the evaluation of this paper.

\section{References}

Alley, R. B., D. E. Lawson, G. J. Larson, E. B. Evenson, and G. S. Baker (2003), Stabilizing feedbacks in glacier bed erosion, Nature, 424, 758-760, doi:10.1038/nature01839.

Anandakrishnan, S., D. D. Blankenship, R. B. Alley, and P. L. Stoffa (1998), Influence of subglacial geology on the position of a West Antarctic ice stream from seismic observations, Nature, 394, 62-65, doi:10.1038/ 27889.

Anandakrishnan, S., G. Catania, R. B. Alley, and H. J. Horgan (2007), Discovery of till deposition at the grounding line of Whillans Ice Stream, Science, 315, 1835-1838, doi:10.1126/science.1138393.

Bamber, J. L., J. L. Gomez-Dans, and J. A. Briggs (2009), A new 1 km digital elevation model of the Antarctic derived from combined satellite 
radar and laser data-Part 1: Data and methods, Cryosphere, 3, 101-111, doi:10.5194/tc-3-101-2009.

Bentley, C. R., and N. A. Ostenso (1961), Glacial and subglacial topography of West Antarctica, J. Glaciol., 3, 882-911.

Björnsson, H. (1996), Scales and rates of glacial sediment removal: A $20 \mathrm{~km}$ long, $300 \mathrm{~m}$ deep trench created beneath Breiðamerkurjökull during the Little Ice Age, Ann. Glaciol., 22, 141-146.

Chen, J. L., C. R. Wilson, B. D. Tapley, D. Blankenship, and D. Young (2008), Antarctic regional ice loss rates from GRACE, Earth Planet Sci. Lett., 266, 140-148, doi:10.1016/j.epsl.2007.10.057.

Corr, H. F. J., C. S. M. Doake, A. Jenkins, and D. G. Vaughan (2001), Investigations of an "ice plain" in the mouth of Pine Island Glacier, Antarctica, J. Glaciol., 47, 51-57, doi:10.3189/172756501781832395.

Cuffey, K. M., and W. S. B. Paterson (2010), The Physics of Glaciers, 4th ed., Butterworth-Heinemann, Oxford, U. K

Hallet, B., L. Hunter, and J. Bogen (1996), Rates of erosion and sediment evacuation by glaciers: A review of field data and their implications, Global Planet. Change, 12, 213-235, doi:10.1016/0921-8181(95) 00021-6.

Helsen, M. M., M. R. van den Broeke, R. S. W. van der Waal, W. J. van den Berg, E. van Meijgaard, C. H. Davis, Y. Li, and I. Goodwin (2008), Elevation changes in Antarctica mainly determined by accumulation variability, Science, 320, 1626-1629, doi:10.1126/science.1153894.

Hildes, D. H. D., G. K. C. Clarke, G. E. Flowers, and S. J. Marshall (2004), Subglacial erosion and englacial sediment transport modelled for North American ice sheets, Quat. Sci. Rev., 23, 409-430, doi:10.1016/ j.quascirev.2003.06.005.

Ivins, E. R., and T. S. James (2005), Antarctic glacial isostatic adjustment: A new assessment, Antarct. Sci., 17, 541-553, doi:10.1017/ S0954102005002968.

Jordan, T. A., F. Ferraccioli, D. G. Vaughan, J. W. Holt, H. Corr, D. D. Blankenship, and T. M. Diehl (2010), Aerogravity evidence for major crustal thinning under the Pine Island Glacier region (West Antarctica), Geol. Soc. Am. Bull., 122, 714-726, doi:10.1130/B26417.1.

Joughin, I., B. E. Smith, and D. M. Holland (2010), Sensitivity of 21st century sea level to ocean-induced thinning of Pine Island Glacier, Antarctica, Geophys. Res. Lett., 37, L20502, doi:10.1029/2010GL044819.

Lawson, D. E. (1993), Glaciohydrologic and Glaciohydraulic Effects on Runoff and Sediment Yield in Glacierized Basins, CRREL Monogr., vol. 93-2, Cold Reg. Res. and Eng. Lab., Hanover, N. H.

Lowe, A. L., and J. B. Anderson (2002), Reconstruction of the West Antarctic ice sheet in Pine Island Bay during the Last Glacial Maximum and its subsequent retreat history, Quat. Sci. Rev., 21, 1879-1897, doi:10.1016/S0277-3791(02)00006-9.

Lowe, A. L., and J. B. Anderson (2003), Evidence for abundant subglacial meltwater beneath the paleo-ice sheet in Pine Island Bay, Antarctica, J. Glaciol., 49, 125-138, doi:10.3189/172756503781830971.

Morelli, C., C. Gantar, T. Honasalo, R. K. McConnell, J. G. Tanner, B. Szabo, U. Uotila, and C. T. Whalen (1974), The International Gravity Standardization Net 1971, Int. Assoc. of Geod. Spec. Publ., vol. 4, 194 pp., Union Géod. et Géophys. Int., Paris.

Motyka, R. J., M. Truffer, E. M. Kuriger, and A. K. Bucki (2006), Rapid erosion of soft sediments by tidewater glacier advance: Taku Glacier, Alaska, USA, Geophys. Res. Lett., 33, L24504, doi:10.1029/ 2006GL028467.

Nolan, M., R. J. Motyka, K. Echelmeyer, and D. C. Trabant (1995), Ice-thickness measurements of Taku Glacier, Alaska, U.S.A., and their relevance to its recent behavior, J. Glaciol., 41, 541-553.
Pritchard, H. D., R. J. Arthern, D. G. Vaughan, and L. A. Edwards (2009), Extensive dynamic thinning on the margins of the Greenland and Antarctic ice sheets, Nature, 461, 971-975, doi:10.1038/nature08471.

Rignot, E. (1998), Fast recession of a West Antarctic glacier, Science, 281, 549-551, doi:10.1126/science.281.5376.549.

Rignot, E. (2008), Changes in West Antarctic ice stream dynamics observed with ALOS PALSAR data, Geophys. Res. Lett., 35, L12505, doi:10.1029/2008GL033365.

Rignot, E., et al. (2004), Improved estimate of the mass balance of glaciers draining into the Amundsen Sea of West Antarctica from CECS/NASA 2002 campaign, Ann. Glaciol., 39, 231-237, doi:10.3189/ 172756404781813916.

Riva, R. E. M., B. C. Gunter, T. J. Urban, B. L. A. Vermeersen, R. C. Lindenbergh, M. M. Helsen, J. L. Bamber, R. S. W. van de Wal, M. R. van den Broeke, and B. E. Schutz (2009), Glacial isostatic adjustment over Antarctica from combined ICESat and GRACE satellite data, Earth Planet. Sci. Lett., 288, 516-523, doi:10.1016/j.eps1.2009.10.013.

Scott, J. B. T., G. H. Gudmundsson, A. M. Smith, R. G. Bingham, H. D. Pritchard, and D. G. Vaughan (2009), Increased rate of acceleration on Pine Island Glacier strongly coupled to changes in gravitational driving stress, Cryosphere., 3, 125-131, doi:10.5194/tc-3-125-2009.

Scott, J., A. Smith, T. Jordan, F. Ferraccioli, R. Bingham, and D. Vaughan (2010), Water at the bed of Pine Island Glacier, Geophys. Res. Abstr., 12 Abstract EGU2010-12284.

Shepherd, A., D. J. Wingham, A. D. Mansley, and H. F. J. Corr (2001), Inland thinning of Pine Island Glacier, West Antarctica, Science, 291, 862-864, doi:10.1126/science.291.5505.862.

Shimizu, H. (1964), Glaciological studies in West Antarctica, 1960-1962, in Antarctic Snow and Ice Studies, Antarct. Res. Ser., vol. 2, pp. 37-64, AGU, Washington, D. C.

Smith, A. M. (1997), Basal conditions on Rutford Ice Stream, West Antarctica, from seismic observations, J. Geophys. Res., 102, 543-552, doi:10.1029/96JB02933.

Smith, A. M., and J. B. T. Scott (2007), Basal conditions on Pine Island Glacier, paper presented at 2007 WAIS/FRISP Workshop, West Antarct. Ice Sheet Initiative, Sterling, Va., 5-8 Sept.

Smith, A. M., T. Murray, K. W. Nicholls, K. Makinson, G. Aðalgeirsdóttir, A. E. Behar, and D. G. Vaughan (2007), Rapid erosion, drumlin formation and changing hydrology beneath an Antarctic ice stream, Geology, 35, 127-130, doi:10.1130/G23036A.1.

Thomas, R. H., et al. (2004), Accelerated sea-level rise from West Antarctica, Science, 306, 255-258, doi:10.1126/science.1099650.

van den Broeke, M. R., J. L. Bamber, J. Lenaerts, and E. Rignot (2011), Ice sheets and sea level: Thinking outside the box, Surv. Geophys., 32, 495-505, doi:10.1007/s10712-011-9137-z.

Vaughan, D. G., H. F. J. Corr, F. Ferraccioli, N. Frearson, A. O'Hare, D. Mach, J. W. Holt, D. D. Blankenship, D. A. Morse, and D. A. Young (2006), New boundary conditions for the West Antarctic Ice Sheet: Subglacial topography beneath Pine Island Glacier, Geophys. Res. Lett. 33, L09501, doi:10.1029/2005GL025588.

Wingham, D. J. (2000), Small fluctuations in the density and thickness of a dry firn column, J. Glaciol., 46, 399-411, doi:10.3189/ 172756500781833089

Wingham, D. J., D. W. Wallis, and A. Shepherd (2009), Spatial and temporal evolution of Pine Island Glacier thinning, 1995-2006, Geophys. Res. Lett., 36, L17501, doi:10.1029/2009GL039126. 